\title{
Establishment of biochemistry reference values for healthy Tanzanian infants, children and adolescents in Kilimanjaro Region
}

\author{
Ann M. Buchanan ${ }^{1,2,3}$, Suzanne P. Fiorillo ${ }^{4}$, Michael W. Omondi ${ }^{2}$, Coleen K. Cunningham ${ }^{1}$ and \\ John A. Crump $3,5,6,7$ \\ 1 Division of Infectious Diseases, Department of Pediatrics, Duke University, Durham, NC, US \\ 2 Kilimanjaro Christian Medical Centre, Moshi, Tanzania \\ 3 Duke Global Health Institute, Duke University, Durham, NC, USA \\ 4 Division of Infectious Diseases, University of Colorado, Denver School of Medicine, Aurora, CO, USA \\ 5 Kilimanjaro Christian Medical University College, Tumaini University, Moshi, Tanzania \\ 6 Division of Infectious Diseases and International Health, Department of Medicine, Duke University, Durham, NC, USA \\ 7 Centre for International Health, Dunedin School of Medicine, University of Otago, Dunedin, New Zealand
}

\begin{abstract}
OBJECTIVE To establish common biochemistry reference intervals for Tanzanian infants, children and adolescents living in the Kilimanjaro Region.

METHODS We recruited healthy, HIV-uninfected Tanzanian infants, children and youth between the ages of 1 month and 17 years from local schools and clinics to participate in this study. Only afebrile children without signs of physical or chronic illness were enrolled. Nonparametric methods were used to determine $95 \%$ reference limits and their $90 \%$ confidence intervals, with outliers removed by the Tukey method.

REsults A total of 619 healthy infants, children and adolescents were enrolled into the study. Twenty-three biochemistry parameters were measured. Compared to US reference intervals, several of the biochemistry parameters showed notable differences, namely alkaline phosphatase, phosphorus, amylase and lipase. Comparing our data to the US National Institutes of Health (NIH) Division of AIDS (DAIDS) grading criteria for classification of adverse events, we found that for selected parameters, up to $15 \%$ of infants or children in certain age groups would have been categorised as having an adverse event as defined by DAIDS.

CONCLUSIONS Our study further confirms the need to use locally established reference intervals to define reference laboratory parameters among children in Africa, rather than relying on those derived from US or European populations. To our knowledge, this study provides the first set of locally validated biochemistry reference ranges for a paediatric population in Tanzania.
\end{abstract}

keywords reference interval, biochemistry, children, paediatric, sub-Saharan Africa, Tanzania

\section{Introduction}

Few data exist on biochemistry reference intervals for healthy infants, children and adolescents in sub-Saharan Africa. Most reference intervals currently in use are derived from North American or European populations and may not be reflective of population values elsewhere. Interpretation of laboratory results using reference ranges established elsewhere in dissimilar populations is potentially problematic for both clinical care and for clinical trials participation. The proper medical evaluation of children is largely dependent on correct interpretation of laboratory results. Such interpretation requires relevant reference intervals, ideally established in the local setting. Relying on reference intervals from other countries or regions may lead to inappropriate clinical management of children and an underestimation or overestimation of disease states $[1,2]$. Locally validated reference ranges are also important for clinical trials participation, as the use of inappropriate clinical laboratory reference ranges may result in an unnecessary exclusion of patients from participation in important trials or an inability to reliably assess drug-related toxicities and adverse events.

It is well established that differences occur in haematologic and immunologic parameters among African children compared to their European or North American 
A. M. Buchanan et al. Biochemistry parameters for Tanzanian youth

counterparts. Multiple studies have shown lower haemoglobin values for African children compared to children from the Western Hemisphere [3-5]. The 2.5th percentiles for haemoglobin, haematocrit and mean corpuscular volume (MCV), for example, are substantially lower for Tanzanian children compared to North American ranges [6]. Whether differences also exist for biochemistry reference intervals is largely unknown.

The aim of this study was to determine the local reference ranges for biochemistry values among a healthy paediatric and adolescent population living in the Kilimanjaro Region of northern Tanzania. Values based on age and gender were also determined, and local results were compared to levels reported in children in North America to the DAIDS toxicity grading tables commonly used in clinical trials.

\section{Methods}

\section{Study population and recruitment}

Healthy Tanzanian paediatric participants aged $\geq 1$ month to $<18$ years of age were recruited and enrolled from schools and clinics in the Kilimanjaro Region located in northern Tanzania from October 2009 through September 2011. The majority of participants were native Tanzanians of black African descent. The predominant tribes in the Kilimanjaro Region are the Chagga, who are primarily smallholder farmers, and the Maasai, who are mostly semi-nomadic peoples residing in both Tanzania and Kenya. In general, Tanzania is characterised by high levels of poverty, with more than two-thirds of the population living below \$1.25 USD per day in 2014; a fast growing population, currently approaching 50 million; and poor health indices with an average life expectancy of 61 years, a maternal mortality ratio at 460 maternal deaths per 100000 live births, an infant mortality rate at 38 per 1000 live births, and an under 5 mortality rate at 54 per 1000 children. The country has shown modest declines in HIV seroprevalence, which was at $5.1 \%$ in 2011-2012 for adults aged 15-49 years vs. 5.7\% in 2007-2008 [7].

Moshi is the administrative capital of Kilimanjaro Region and sits at an altitude of $810 \mathrm{~m}$ above sea level. While Tanzania still ranks quite low on the human development index, Kilimanjaro Region in general is one of the wealthier areas of the country. There are two rainy seasons in Moshi, a long rainy season between March and May, and a second short rainy season between October and December [8]. Malaria transmission intensity is low [9]. Of 467 infants and children enrolled into a febrile illness study in Moshi in 2007-08, more than 60\% were given a clinical diagnosis of malaria, although laboratory confirmation was found in only $1.3 \%$. It is increasingly recognised that malaria is overdiagnosed in many regions of the world, particularly with the growing use of malaria diagnostic tests for patients who are present with fever. In this particular study, bacterial zoonoses such as leptospirosis, brucellosis, Q fever and spotted fever group rickettsioses were isolated in up to $20 \%$ of febrile hospital admissions [10]. Malnutrition is also common among children in the Kilimanjaro Region; one recent study in the region showed $44 \%$ of children $<3$ years were stunted and $19 \%$ were underweight according to World Health Organisation (WHO) definitions [11]).

After obtaining permission from the Regional and District Medical Officers, local Reproductive and Child Health Clinics and their surrounding primary and secondary schools were visited by the study nurses who explained the study to administrators and potential participants. Announcements regarding optional study participation were also relayed through local places of worship.

All children were screened for the presence of fever $\left(\geq 38.0^{\circ} \mathrm{C}\right)$ with an axillary temperature and were excluded from participation and referred to the local clinic if found to be febrile. Any child with other physical complaints or found to be ill on examination was also excluded and referred. Children with chronic illnesses or taking any medications on a regular basis were excluded from participation. Finally, adolescent females with any suspicion of pregnancy were screened with a urine pregnancy test (Sure-Vue ${ }^{\mathrm{TM}}$ STAT Serum/Urine hCG Test Kit, Fisher Healthcare $^{\mathrm{TM}}$, Fisher Scientific, Houston, TX, USA).

\section{Blood collection and laboratory methods}

Four to ten millilitres of whole blood (according to patient weight) was collected by antecubital venipuncture with a Vacutainer system (Becton Dickinson Biosciences, San Jose, CA, USA) between 8 am and 12 pm. Two millilitres was placed into an EDTA tube for HIV serology performed according to Tanzania's national algorithm, which at the time used the following two rapid tests in parallel: SD Bioline HIV-1/2 antibody (Standard Diagnostics, Inc., South Korea) and Determine HIV-1/2 antibody (Abbott Laboratories, Abbott Park, IL, USA) [12]. Patients who tested seropositive for HIV were excluded from the study and immediately referred to the local HIV care and treatment clinic for further testing and counselling. The remaining 2-8 $\mathrm{ml}$ of blood was placed in a standard plain tube for the chemistry 
A. M. Buchanan et al. Biochemistry parameters for Tanzanian youth

analyses. Samples were transferred to the laboratory within $2 \mathrm{~h}$ of specimen collection and processed immediately at the Kilimanjaro Christian Research Institute (KCRI) Biotechnology Laboratory, which successfully participates in College of American Pathologist (CAP) external quality assurance programmes.

All biochemistry analyte test kits were US Food and Drug Administration-approved, testing was performed according to manufacturers' instructions, and all procedures were performed according to good clinical laboratory practices. Serum samples were analysed for the following: albumin, alkaline phosphatase, alanine aminotransferase (ALAT), aspartate aminotransferase (ASAT), amylase, total bilirubin, calcium, cholesterol, creatinine kinase, bicarbonate, chloride, creatinine, glucose, highdensity lipoprotein (HDL), low-density lipoprotein (LDL), potassium, lipase, phosphorus, magnesium, sodium, total protein, triglycerides and urea. All analyses were performed using the Cobas Integra 400 plus biochemistry analyser (Roche Diagnostics, Germany), according to the manufacturer's instructions.

\section{Ethical approval}

The study was approved by an Institutional Review Board of Duke University, the Kilimanjaro Christian Medical Centre (KCMC) Research Ethics Committee and the Tanzania National Institute for Medical Research National Research Ethics Coordinating Committee. Written informed consent was obtained prior to study entry for all participants in the local language of Kiswahili. Verbal assent was additionally obtained for all children aged 9 and above. Additionally, children aged 12 and above provided written consent along with their parent/ legal guardian.

\section{Statistical analysis}

Statistical analysis was performed with Excel (Microsoft Corp., Redmond, WA, USA) and SAS Version 9.4 (SAS Institute, Cary, NC, USA). Data were initially transformed to an approximate Gaussian distribution using the Box-Cox transformation method [13]. Based on the assumption that data are likely skewed and that outliers will also exist, Horn et al. proposed a two-stage detection technique to balance these two assumptions [14]. The data are first transformed to an approximate normal distribution using Box-Cox methods and then using nonparametric methods [15] to detect outliers from the normal distribution. This two-stage process has been identified as a robust method for identifying outliers for computing laboratory reference ranges. Potential outliers were first identified by visual inspection and then confirmed by the Tukey method [15]. The Tukey method involved computing the upper and lower limits ('fences') based on the quartiles and the interquartile range of the transformed data. Values outside these fences were considered outliers and removed from the final reference estimation [14]. Values were excluded for each analyte within each age group. The number of exclusions varied from 0 to 6 depending on analyte/age group. The upper and lower reference limits were determined as the 2.5 th and 97.5th percentiles (95\% reference interval) of the cleaned data. The reference median and the $90 \%$ confidence intervals around both the upper and lower limits were also calculated, according to the methods in Hahn [16].

Children were divided into age cohorts of $<12$ months, $\geq 1$ to $<5$ years, $\geq 5$ to $<13$ years and $\geq 13$ to $<18$ years. The oldest age cohort was further subdivided by gender. We attempted to enrol a minimum of 120 children into each cohort, as recommended by the Clinical and Laboratory Standards Institute (CLSI) guidelines for the establishment of reference ranges (Clinical and Laboratory Standards Institute [17] 2008). Finally, we compared our data against US-derived reference intervals from the Harriet Lane Handbook [18] and the US NIH DAIDS Toxicity Tables [19] to determine the frequency at which values from these cohort would qualify as an adverse event as defined by DAIDS criteria. Only those biochemical parameters that had reference ranges qualifying as a DAIDS Grade 1 or higher were included in the analysed results.

\section{Results}

A total of 633 children were screened for study participation; 12 were excluded due to the presence of fever; and two were excluded because of a positive HIV-1 antibody test. No females were excluded due to a positive urine pregnancy test. In total, 619 children met all eligibility criteria and were enrolled into the study. Within each age cohort, single values were excluded if they met the criteria for outliers as described in the methods section. The age range was 1 month to $<18$ years. Table 1 shows the median value and $95 \%$ reference interval (RI) for each of five age groups: $<12$ months, $\geq 1$ to $<5$ years, $\geq 5$ to $<13$ years and $\geq 13$ to $<18$ years. The oldest age cohort is further analysed by gender.

Several chemistry parameters showed notable differences compared to the US-derived reference intervals (Table 1). Alkaline phosphatase among US infants ranges from 150 to $420 \mathrm{U} / \mathrm{l}$ [18], and in our infant cohort, the range extended up to $589 \mathrm{U} / \mathrm{l}$. For adolescent males and females, the US reference ranges extend to 390 and 
A. M. Buchanan et al. Biochemistry parameters for Tanzanian youth

Table I Biochemistry reference values for Tanzanian children by age (with Medians, $95 \%$ reference intervals, and comparison to US reference values)

\begin{tabular}{|c|c|c|c|c|c|c|}
\hline Analyte & Age & $\mathrm{N}$ & Median & $\begin{array}{l}95 \% \text { RI } \\
\text { Tanzania }\end{array}$ & Age & $\begin{array}{l}\text { Ref value } \\
\text { US [18] }\end{array}$ \\
\hline \multirow[t]{5}{*}{$\operatorname{ALAT}(\mathrm{U} / \mathrm{l})$} & $<12$ months & 121 & 17 & $9-33$ & $\begin{array}{c}<12 \text { months } \\
1-3 \text { years }\end{array}$ & $\begin{array}{r}13-45 \\
5-45\end{array}$ \\
\hline & $\geq 1$ to $<5$ years & 123 & 15 & $10-28$ & $\begin{array}{l}\text { 4-6 years } \\
7-9 \text { years }\end{array}$ & $\begin{array}{c}10-25 \\
10-35\end{array}$ \\
\hline & $\geq 5$ to $<13$ years & 120 & 17 & $9-35$ & $\begin{array}{l}10-11 \text { years } \\
12-13 \text { years }\end{array}$ & $\begin{array}{l}10-35 \\
10-55\end{array}$ \\
\hline & $\geq 13$ to $<18$ years $(\mathrm{F})$ & 123 & 15 & $7-33$ & $\begin{array}{l}14-15(\mathrm{~F}) \\
14-15(\mathrm{M})\end{array}$ & $\begin{array}{r}5-30 \\
10-45\end{array}$ \\
\hline & $\geq 13$ to $<18$ years $(\mathrm{M})$ & 122 & 17 & $10-36$ & $\begin{array}{l}>16(\mathrm{~F}) \\
>16(\mathrm{M})\end{array}$ & $\begin{array}{r}5-35 \\
10-40\end{array}$ \\
\hline \multirow[t]{5}{*}{ Albumin $(\mathrm{g} / \mathrm{l})$} & $<12$ months & 121 & 43 & $36-48$ & & \\
\hline & $\geq 1$ to $<5$ years & 123 & 44 & $40-49$ & $1-2$ years & $36-52$ \\
\hline & $\geq 5$ to $<13$ years & 120 & 45 & $40-48$ & $3-16$ years & $36-52$ \\
\hline & $\geq 13$ to $<18$ years $(\mathrm{F})$ & 121 & 45 & $40-49$ & $\geq 16$ years & $39-51$ \\
\hline & $\geq 13$ to $<18$ years $(\mathrm{M})$ & 121 & 46 & $41-51$ & & \\
\hline \multirow[t]{5}{*}{ Alkaline phosphatase (U/l) } & $<12$ months & 122 & 307 & $164-589$ & Infant & $150-420$ \\
\hline & $\geq 1$ to $<5$ years & 123 & 253 & $153-410$ & $2-10$ years & $100-320$ \\
\hline & $\geq 5$ to $<13$ years & 121 & 278 & $174-460$ & $2-10$ years & $100-320$ \\
\hline & $\geq 13$ to $<18$ years $(\mathrm{F})$ & 123 & 191 & $68-498$ & Adolescent females & $100-320$ \\
\hline & $\geq 13$ to $<18$ years $(\mathrm{M})$ & 118 & 302 & $124-537$ & Adolescent males & $100-390$ \\
\hline \multirow[t]{5}{*}{ Amylase (U/l) } & $<12$ months & 119 & 41 & 6-183 & $\begin{array}{l}3-6 \text { months } \\
6-12 \text { months }\end{array}$ & $\begin{array}{l}0-50 \\
0-80\end{array}$ \\
\hline & $\geq 1$ to $<5$ years & 124 & 96 & $31-174$ & $>1$ year & $30-100$ \\
\hline & $\geq 5$ to $<13$ years & 122 & 109 & $57-246$ & & \\
\hline & $\geq 13$ to $<18$ years $(\mathrm{F})$ & 120 & 97 & $55-181$ & & \\
\hline & $\geq 13$ to $<18$ years $(\mathrm{M})$ & 120 & 99 & $56-175$ & & \\
\hline \multirow[t]{5}{*}{ ASAT (U/l) } & $<12$ months & 120 & 38 & $26-65$ & 10 days -24 months & $9-80$ \\
\hline & $\geq 1$ to $<5$ years & 120 & 36 & $27-55$ & $\begin{array}{l}>24 \text { months }(\mathrm{F}) \\
>24 \text { months }(\mathrm{M})\end{array}$ & $\begin{array}{l}13-35 \\
15-40\end{array}$ \\
\hline & $\geq 5$ to $<13$ years & 120 & 31 & $21-51$ & & \\
\hline & $\geq 13$ to $<18$ years $(\mathrm{F})$ & 123 & 23 & $17-36$ & & \\
\hline & $\geq 13$ to $<18$ years $(\mathrm{M})$ & 120 & 27 & $19-42$ & & \\
\hline \multirow[t]{5}{*}{ Bicarbonate $(\mathrm{mmol} / \mathrm{l})$} & $<12$ months & 121 & 16 & $12-21$ & 2 months -2 years & $16-24$ \\
\hline & $\geq 1$ to $<5$ years & 122 & 17 & $13-21$ & $>2$ years & $22-26$ \\
\hline & $\geq 5$ to $<13$ years & 123 & 20 & $16-24$ & & \\
\hline & $\geq 13$ to $<18$ years $(F)$ & 122 & 21 & $15-24$ & & \\
\hline & $\geq 13$ to $<18$ years $(\mathrm{M})$ & 122 & 22 & $17-26$ & & \\
\hline \multirow[t]{5}{*}{ Bilirubin, total $(\mu \mathrm{mol} / \mathrm{l})$} & $<12$ months & 117 & 4 & 2-19 & Term Infant, $>5$ days & $<21$ \\
\hline & $\geq 1$ to $<5$ years & 122 & 4 & $2-9$ & & \\
\hline & $\geq 5$ to $<13$ years & 122 & 4 & $2-11$ & & \\
\hline & $\geq 13$ to $<18$ years $(\mathrm{F})$ & 120 & 6 & $3-22$ & & \\
\hline & $\geq 13$ to $<18$ years $(\mathrm{M})$ & 116 & 6 & $2-15$ & Adult & $<20.5$ \\
\hline \multirow[t]{5}{*}{ Calcium (mmol/l) } & $<12$ months & 110 & 2.6 & $2.40-2.80$ & $0-10$ days & $1.9-2.6$ \\
\hline & $\geq 1$ to $<5$ years & 96 & 2.5 & $2.20-2.70$ & 10 days -24 months & $2.25-2.75$ \\
\hline & $\geq 5$ to $<13$ years & 97 & 2.4 & $2.20-2.56$ & 24 months -12 years & $2.2-2.7$ \\
\hline & $\geq 13$ to $<18$ years $(\mathrm{F})$ & 108 & 2.4 & $2.20-2.60$ & $12-18$ years & $2.1-2.55$ \\
\hline & $\geq 13$ to $<18$ years $(\mathrm{M})$ & 105 & 2.4 & $2.18-2.60$ & & \\
\hline \multirow[t]{6}{*}{ Chloride (mmol/l) } & $<12$ months & 120 & 104 & $100-107$ & 0-6 months & $97-108$ \\
\hline & & & & & 6-12 months & $97-106$ \\
\hline & $\geq 1$ to $<5$ years & 124 & 104 & $100-108$ & Child/adult & $97-107$ \\
\hline & $\geq 5$ to $<13$ years & 123 & 103 & 98-108 & & \\
\hline & $\geq 13$ to $<18$ years $(\mathrm{F})$ & 121 & 102 & $99-106$ & & \\
\hline & $\geq 13$ to $<18$ years $(\mathrm{M})$ & 122 & 101 & 98-105 & & \\
\hline
\end{tabular}


A. M. Buchanan et al. Biochemistry parameters for Tanzanian youth

Table I (Continued)

\begin{tabular}{|c|c|c|c|c|c|c|}
\hline Analyte & Age & $\mathrm{N}$ & Median & $\begin{array}{l}95 \% \text { RI } \\
\text { Tanzania }\end{array}$ & Age & $\begin{array}{l}\text { Ref value } \\
\text { US [18] }\end{array}$ \\
\hline \multirow[t]{5}{*}{ Cholesterol (mmol/l) } & $<12$ months & 120 & 3.69 & $2.10-5.68$ & & \\
\hline & $\geq 1$ to $<5$ years & 121 & 3.49 & $2.51-5.29$ & & \\
\hline & $\geq 5$ to $<13$ years & 123 & 3.53 & $2.11-4.91$ & Child adolescent & Desirable: $<4.40$ \\
\hline & $\geq 13$ to $<18$ years $(F)$ & 121 & 3.73 & $2.59-5.13$ & Child adolescent & High: $>5.18$ \\
\hline & $\geq 13$ to $<18$ years $(\mathrm{M})$ & 120 & 3.43 & $2.35-4.56$ & & \\
\hline \multirow[t]{5}{*}{ Creatinine $(\mu \mathrm{mol} / \mathrm{l})$} & $<12$ months & 117 & 18 & $12-28$ & Infant & $18-35$ \\
\hline & $\geq 1$ to $<5$ years & 117 & 24 & $15-50$ & Child & $27-62$ \\
\hline & $\geq 5$ to $<13$ years & 116 & 36 & $24-49$ & & \\
\hline & $\geq 13$ to $<18$ years $(\mathrm{F})$ & 119 & 45 & $32-64$ & & \\
\hline & $\geq 13$ to $<18$ years $(\mathrm{M})$ & 117 & 48 & $36-80$ & Adolescent & $44-88$ \\
\hline \multirow[t]{5}{*}{ Creatinine kinase (U/l) } & $<12$ months & 114 & 113 & $45-227$ & & \\
\hline & $\geq 1$ to $<5$ years & 97 & 127 & $73-248$ & & \\
\hline & $\geq 5$ to $<13$ years & 96 & 139 & $83-294$ & & \\
\hline & $\geq 13$ to $<18$ years $(F)$ & 106 & 140 & $81-238$ & $>6$ weeks to adult $(\mathrm{F})$ & $20-180$ \\
\hline & $\geq 13$ to $<18$ years $(\mathrm{M})$ & 117 & 199 & $82-604$ & $>6$ weeks to adult $(\mathrm{M})$ & $20-200$ \\
\hline \multirow[t]{5}{*}{ Glucose $(\mathrm{mmol} / \mathrm{l})$} & $<12$ months & 123 & 4.2 & $2.9-5.5$ & Newborn, $>1$ day & $2.8-5.0$ \\
\hline & $\geq 1$ to $<5$ years & 122 & 4.1 & $3.0-5.4$ & Child & $3.3-5.5$ \\
\hline & $\geq 5$ to $<13$ years & 119 & 4.1 & $2.7-5.3$ & & \\
\hline & $\geq 13$ to $<18$ years $(\mathrm{F})$ & 122 & 4.1 & $2.8-5.1$ & & \\
\hline & $\geq 13$ to $<18$ years $(\mathrm{M})$ & 120 & 4.3 & $3.0-5.2$ & $>16$ years & $3.9-5.8$ \\
\hline \multirow[t]{5}{*}{$\mathrm{HDL}(\mathrm{mmol} / \mathrm{l})$} & $<12$ months & 113 & 0.86 & $0.32-1.53$ & & \\
\hline & $\geq 1$ to $<5$ years & 119 & 1.00 & $0.61-1.69$ & & \\
\hline & $\geq 5$ to $<13$ years & 121 & 1.21 & $0.75-1.96$ & Child adolescent & $>0.91$ : Desirable \\
\hline & $\geq 13$ to $<18$ years $(F)$ & 119 & 1.22 & $0.77-1.87$ & & \\
\hline & $\geq 13$ to $<18$ years $(\mathrm{M})$ & 121 & 1.19 & $0.64-1.91$ & & \\
\hline \multirow[t]{6}{*}{ Lipase (U/l) } & $<12$ months & 123 & 18.7 & $10.8-34.2$ & $1-6$ months & $4-29$ \\
\hline & & & & & 6-12 months & $4-23$ \\
\hline & $\geq 1$ to $<5$ years & 124 & 23.0 & $12.4-50.4$ & $>1$ year & $3-32$ \\
\hline & $\geq 5$ to $<13$ years & 121 & 23.0 & $15.5-34.8$ & & \\
\hline & $\geq 13$ to $<18$ years $(\mathrm{F})$ & 123 & 23.6 & $14.7-48.9$ & & \\
\hline & $\geq 13$ to $<18$ years $(\mathrm{M})$ & 121 & 22.4 & $13.8-38.0$ & & \\
\hline \multirow[t]{5}{*}{$\mathrm{LDL}(\mathrm{mmol} / \mathrm{l})$} & $<12$ months & 123 & 1.82 & $0.50-3.66$ & & \\
\hline & $\geq 1$ to $<5$ years & 119 & 1.90 & $1.00-3.70$ & & \\
\hline & $\geq 5$ to $<13$ years & 123 & 1.86 & $0.90-3.17$ & Child adolescent & $<2.85$ : Optimal \\
\hline & $\geq 13$ to $<18$ years $(\mathrm{F})$ & 123 & 2.12 & $1.23-3.12$ & Child adolescent & $>3.37:$ High \\
\hline & $\geq 13$ to $<18$ years $(\mathrm{M})$ & 121 & 1.80 & $0.96-2.81$ & & \\
\hline \multirow[t]{5}{*}{ Magnesium (mmol/l) } & $<12$ months & 123 & 0.95 & $0.84-1.08$ & All ages & $0.63-1.05$ \\
\hline & $\geq 1$ to $<5$ years & 124 & 0.90 & $0.80-1.04$ & & \\
\hline & $\geq 5$ to $<13$ years & 123 & 0.87 & $0.77-0.99$ & & \\
\hline & $\geq 13$ to $<18$ years $(\mathrm{F})$ & 123 & 0.85 & $0.75-0.93$ & & \\
\hline & $\geq 13$ to $<18$ years $(\mathrm{M})$ & 122 & 0.87 & $0.77-0.98$ & & \\
\hline \multirow[t]{5}{*}{ Phosphorus (mmol/l) } & $<12$ months & 122 & 1.94 & $1.56-2.39$ & 10 days -24 months & $1.29-2.10$ \\
\hline & $\geq 1$ to $<5$ years & 122 & 1.70 & $1.30-2.06$ & $3-9$ years & $1.03-1.87$ \\
\hline & $\geq 5$ to $<13$ years & 121 & 1.56 & $1.20-1.90$ & $10-15$ years & $1.07-1.74$ \\
\hline & $\geq 13$ to $<18$ years $(\mathrm{F})$ & 123 & 1.30 & $0.87-1.83$ & $>15$ years & $0.78-1.42$ \\
\hline & $\geq 13$ to $<18$ years $(\mathrm{M})$ & 121 & 1.48 & $0.92-1.79$ & & \\
\hline \multirow[t]{5}{*}{ Potassium $(\mathrm{mmol} / \mathrm{l})$} & $<12$ months & 122 & 5.0 & $4.2-6.5$ & Infant & $4.1-5.3$ \\
\hline & $\geq 1$ to $<5$ years & 124 & 4.6 & $3.8-5.9$ & Child & $3.4-4.7$ \\
\hline & $\geq 5$ to $<13$ years & 123 & 4.2 & $3.2-5.2$ & & \\
\hline & $\geq 13$ to $<18$ years $(F)$ & 122 & 4.2 & $3.6-5.0$ & & \\
\hline & $\geq 13$ to $<18$ years $(\mathrm{M})$ & 118 & 4.3 & $3.6-5.1$ & Adult & $3.5-5.1$ \\
\hline
\end{tabular}


A. M. Buchanan et al. Biochemistry parameters for Tanzanian youth

Table I (Continued)

\begin{tabular}{|c|c|c|c|c|c|c|}
\hline Analyte & Age & $\mathrm{N}$ & Median & $\begin{array}{l}95 \% \text { RI } \\
\text { Tanzania }\end{array}$ & Age & $\begin{array}{l}\text { Ref value } \\
\text { US [18] }\end{array}$ \\
\hline \multirow[t]{5}{*}{ Protein, Total (g/l) } & $<12$ months & 119 & 63 & $52-76$ & & \\
\hline & $\geq 1$ to $<5$ years & 121 & 68 & $60-76$ & $1-2$ years & $56-75$ \\
\hline & $\geq 5$ to $<13$ years & 122 & 72 & $66-80$ & $3-16$ years & $60-80$ \\
\hline & $\geq 13$ to $<18$ years $(F)$ & 123 & 73 & $67-84$ & $\geq 16$ years & $60-83$ \\
\hline & $\geq 13$ to $<18$ years $(\mathrm{M})$ & 121 & 75 & $68-84$ & & \\
\hline \multirow[t]{5}{*}{ Sodium (mmol/l) } & $<12$ months & 117 & 136 & 133-139 & $<1$ year & $130-145$ \\
\hline & $\geq 1$ to $<5$ years & 124 & 137 & $133-141$ & $>1$ year & $135-147$ \\
\hline & $\geq 5$ to $<13$ years & 123 & 137 & $134-141$ & & \\
\hline & $\geq 13$ to $<18$ years $(F)$ & 121 & 137 & $134-140$ & & \\
\hline & $\geq 13$ to $<18$ years $(\mathrm{M})$ & 122 & 137 & $134-140$ & & \\
\hline \multirow[t]{5}{*}{ Triglycerides (mmol/l) } & $<12$ months & 123 & 1.60 & $0.67-3.06$ & $1-3$ years & $0.31-0.41$ \\
\hline & $\geq 1$ to $<5$ years & 123 & 0.97 & $0.48-2.65$ & $4-6$ years & $0.36-0.41$ \\
\hline & $\geq 5$ to $<13$ years & 117 & 0.75 & $0.37-1.77$ & $7-9$ years & $0.32-1.46$ \\
\hline & $\geq 13$ to $<18$ years $(\mathrm{F})$ & 123 & 0.83 & $0.35-1.96$ & 10-19 years $(\mathrm{F})$ & $0.42-1.58$ \\
\hline & $\geq 13$ to $<18$ years $(\mathrm{M})$ & 122 & 0.82 & $0.38-2.50$ & 10-19 years $(\mathrm{M})$ & $0.27-1.64$ \\
\hline \multirow[t]{5}{*}{ Urea $(\mathrm{mmol} / \mathrm{l})$} & $<12$ months & 123 & 1.8 & $0.7-3.8$ & Newborn & $0.7-6.7$ \\
\hline & $\geq 1$ to $<5$ years & 124 & 2.6 & $1.3-4.2$ & Infant & $1.8-6.4$ \\
\hline & $\geq 5$ to $<13$ years & 120 & 2.5 & $1.4-4.4$ & Child & $1.8-6.4$ \\
\hline & $\geq 13$ to $<18$ years $(F)$ & 122 & 2.8 & $1.6-4.4$ & Adult & $2.1-7.1$ \\
\hline & $\geq 13$ to $<18$ years $(\mathrm{M})$ & 120 & 2.7 & $1.5-4.5$ & & \\
\hline
\end{tabular}

RI, Reference interval; CI, Confidence interval; (M), Male; ASAT, Aspartate aminotransferase; HDL, High-density lipoprotein; (F), Female; ALAT, Alanine aminotransferase; LDL, Low-density lipoprotein.

$320 \mathrm{U} / \mathrm{l}$, respectively, compared to our cohorts where values approached $500 \mathrm{U} / 1$ and higher. Amylase values for our infant, child and adolescent populations were much higher than standard US parameters (Table 1). Our lipase values are also higher than standard US reference values, but are most notable for our cohorts of children $\geq 1$ to $<5$ years and adolescent girls $\geq 13$ to $<18$ years of age (Table 1). Finally, phosphorus levels for our Tanzanian cohort tended to be higher across all ages compared to US reference ranges (Table 1).

We also compared our data to the DAIDS grading criteria for classification of adverse events [19], and found that for select parameters, up to $15 \%$ of infants or children in certain age categories would be classified as having an adverse event as defined by DAIDS. Among the Tanzanian cohort, the number of children falling outside the reference range based on the DAIDS tables was most notable for low serum glucose across all age ranges, high calcium ranges among infants and young children, and both high and low potassium among two of our child cohorts (Table 2).

\section{Discussion}

The availability of accurate and validated reference intervals is fundamental to the practice of medicine, and there is a genuine need to establish paediatric reference intervals for children in resource-poor settings such as in subSaharan Africa. The main objective of this study was to establish locally validated reference intervals from a healthy Tanzanian paediatric population that can be applied in the future for similar populations. With such reference data lacking, many clinicians and researchers still use American or European-derived intervals which may not be suitable for the population at hand.

While Tanzanian reference intervals for many of the analytes in our study were comparable to US values, four analytes in particular stood out as being quite different. The ranges for alkaline phosphatase for healthy Tanzanian children were higher across all ages compared to US children. Alkaline phosphatase is present throughout the entire body but is predominantly concentrated in the liver, kidneys, bile duct and bones. It is not uncommon for alkaline phosphatase to be elevated in healthy growing children. While our values do not approach those of transient hyperphosphatasemia (TH) which occurs commonly in infants and young children (>1000 U/l) [20], it exceeds the comparable upper bounds of US ranges by as much as 170 units for some ages. We did not perform isoenzyme analysis, so we were unable to investigate the specific source of elevated alkaline phosphatase. 
A. M. Buchanan et al. Biochemistry parameters for Tanzanian youth

Table 2 Frequency of adverse events among paediatric subjects in the Moshi, Tanzania area compared to the Division of AIDS (DAIDS) toxicity grading criteria

\begin{tabular}{|c|c|c|c|c|c|c|c|c|c|c|c|c|c|}
\hline \multirow[b]{2}{*}{ Parameter } & \multirow[b]{2}{*}{ Age range } & \multirow[b]{2}{*}{$\mathrm{n}$} & \multirow[b]{2}{*}{ Units } & \multirow{2}{*}{$\begin{array}{l}\text { Study } \\
\text { reference } \\
\text { interval }\end{array}$} & \multirow{2}{*}{$\begin{array}{l}\text { DAIDS } \\
\text { parameter }\end{array}$} & \multicolumn{2}{|c|}{$\begin{array}{l}\text { DAIDS } \\
\text { Grade } 1\end{array}$} & \multicolumn{2}{|c|}{$\begin{array}{l}\text { DAIDS } \\
\text { Grade } \\
2\end{array}$} & \multicolumn{2}{|c|}{$\begin{array}{l}\text { DAIDS } \\
\text { Grade } \\
3\end{array}$} & \multicolumn{2}{|c|}{$\begin{array}{l}\text { DAIDS } \\
\text { Grade } \\
4\end{array}$} \\
\hline & & & & & & $\mathrm{n}$ & $\%$ & $\mathrm{n}$ & $\%$ & $\mathrm{n}$ & $\%$ & $\mathrm{n}$ & $\%$ \\
\hline \multirow[t]{2}{*}{ Calcium } & $<12$ months & 107 & $\mathrm{mmol} / \mathrm{l}$ & $2.40-2.80$ & Calcium, high & 38 & 35.5 & 0 & 0.0 & 0 & 0.0 & 0 & 0.0 \\
\hline & $\geq 1$ to $<5$ years & 94 & $\mathrm{mmol} / \mathrm{l}$ & $2.20-2.70$ & Calcium, high & 8 & 8.5 & 0 & 0.0 & 0 & 0.0 & 0 & 0.0 \\
\hline \multirow{5}{*}{$\begin{array}{l}\text { Glucose - } \\
\text { non-fasting }\end{array}$} & $<12$ months & 118 & $\mathrm{mmol} / \mathrm{l}$ & $2.9-5.5$ & Glucose, low & 18 & 15.3 & 6 & 5.1 & 0 & 0.0 & 0 & 0.0 \\
\hline & $\geq 1$ to $<5$ years & 116 & $\mathrm{mmol} / \mathrm{l}$ & $3.0-5.4$ & Glucose, low & 16 & 13.8 & 3 & 2.6 & 0 & 0.0 & 0 & 0.0 \\
\hline & $\geq 5$ to $<13$ years & 117 & $\mathrm{mmol} / \mathrm{l}$ & $2.7-5.3$ & Glucose, low & 14 & 12.0 & 8 & 6.8 & 0 & 0.0 & 0 & 0.0 \\
\hline & $\geq 13$ to $<18$ years $(\mathrm{F})$ & 117 & $\mathrm{mmol} / \mathrm{l}$ & $2.8-5.1$ & Glucose, low & 20 & 3.4 & 4 & 3.4 & 0 & 0.0 & 0 & 0.0 \\
\hline & $\geq 13$ to $<18$ years $(\mathrm{M})$ & 117 & $\mathrm{mmol} / \mathrm{l}$ & $3.0-5.2$ & Glucose, low & 10 & 8.5 & 2 & 1.7 & 0 & 0.0 & 0 & 0.0 \\
\hline \multirow[t]{2}{*}{ Potassium } & $\geq 1$ to $<5$ years & 120 & $\mathrm{mmol} / \mathrm{l}$ & $3.8-5.9$ & Potassium, high & 7 & 5.8 & 0 & 0.0 & 0 & 0.0 & 0 & 0.0 \\
\hline & $\geq 5$ to $<13$ years & 119 & $\mathrm{mmol} / \mathrm{l}$ & $3.2-5.2$ & Potassium, low & 3 & 2.5 & 0 & 0.0 & 0 & 0.0 & 0 & 0.0 \\
\hline
\end{tabular}

M, Male; F, Female.

The phosphorus reference range for our Tanzanian population was also higher than US reference ranges across all age groups. The clinical relevance of this is uncertain, and is likely not meaningful as phosphorus reference ranges increase with decreasing age, with premature infants having the highest reference range [21]. The causes of hyperphosphatemia are multiple, and may include endogenous causes of an acute phosphate load such as tumour lysis syndrome or rhabdomyolysis, or exogenous causes such as vitamin D toxicity or phosphate-containing medications such as laxatives [22, 23]. Decreased renal clearance is perhaps the most common cause of hyperphosphatemia, which may be related to acute kidney injury, chronic kidney disease, hypoparathyroidism, pseudohypoparathyroidism and acromegaly, among others [23].

Most interesting from our study are amylase ranges across all age groups, which were higher than the reference ranges listed for healthy US counterparts. The upper limit of normal beyond 1 year of life is $100 \mathrm{U} / \mathrm{l}$ for US children, while our upper limit ranges extended as high as $246 \mathrm{U} / \mathrm{l}$ in some age groups. Similarly, for our infant cohort, the range extended to $183 \mathrm{U} / \mathrm{l}$, while for US ranges, it extends only to $50 \mathrm{U} / \mathrm{l}$ up to the age of 6 months and $80 \mathrm{U} / \mathrm{l}$ up to the age of 12 months. While the lipase reference ranges for our Tanzanian paediatric cohorts are also higher than US counterparts of the same age, the magnitude is not as great as that seen for amylase. There are several possibilities that could explain hyperamylasaemia in our paediatric population. Elevated amylase along with a parallel increase in lipase would point to an inflammatory state of the pancreas, such as pancreatitis. As all of our children were required to be physically well for study entry, such a diagnosis in any child in our cohort is unlikely. Secondly, we did not perform amylase isoenzyme testing, and thus cannot differentiate between salivary and pancreatic amylase, the two major sites of amylase production. As the children in our study were clinically well, a possible explanation for their elevated amylase levels could be what is now termed chronic asymptomatic hyperamylasaemia unrelated to pancreatic diseases (CHUPD) [24]. CHUPD can typically be classified further into macroamylasaemia, benign pancreatic hyperamylasaemia and salivary hyperamylasaemia. Again, without being able to perform isoenzyme testing and urinary amylase levels, we were unable to make these diagnoses. Mortelé et al. assessed the magnetic resonance cholangiopancreatographic findings of patients with asymptomatic hyperamylasaemia and hyperlipasaemia and found that more than $50 \%$ had pancreatic abnormalities, with pancreas divisum in particular being found more often than in the general population [25]. Coeliac disease and cystic fibrosis are two diseases that would typically be entertained in a paediatric patient with persistent pancreatic hyperenzymemia [26], but again, we would expect our patients to show some minimal symptoms or signs if this were the case. Finally, familial hyperamylasaemia is also described in case reports and points to an autosomal dominant pattern of inheritance [27, 28]. Regardless of the aetiology of the hyperenzymemia, especially the hyperamylasaemia these values represent the reference ranges for our Tanzanian paediatric population and may represent no pathology whatsoever.

We specifically chose to compare data from this cohort to the DAIDS grading criteria for adverse events (AE) as 
A. M. Buchanan et al. Biochemistry parameters for Tanzanian youth

this has important implications for clinical trials participation, particularly in sub-Saharan Africa, where recruitment for paediatric HIV studies is often sought. These criteria are a set of descriptive terminology that can be utilised for AE reporting, with a severity scale provided for each AE term. The tables include parameters for both adult and paediatric AEs, and are typically graded from grade 1 (mild) to grade 4 (potentially lifethreatening) [19]. We found that more than $35 \%$ of infants in the present cohort would have been classified as having a grade 1 hypercalcaemia, for example. While grade 1 laboratory abnormalities in and of themselves may not cause clinical symptoms, the classification of a participant's laboratory result as abnormal becomes the problem. If this same participant developed a more marked hypercalcaemia, he or she may be classified as having a grade 3 or 4 laboratory abnormality that may have more serious consequences in terms of study participation. Similarly, almost $7 \%$ of our school-age children had a low serum glucose and almost $6 \%$ of children ages $1-5$ years had a grade 1 hyperkalaemia. Thus, using the DAIDS adverse event grading scale for our population would lead to an over-reporting of adverse events in our paediatric population or to unnecessary exclusion of healthy children from participation because their baseline test results, although normal for the population, may be classified as in the toxicity range.

Our study had several limitations. First, the Clinical and Laboratory Standards Institute (CLSI) guidelines for establishing reference intervals recommends a minimum of 120 observations for each analyte and age range under study, which has the advantage of allowing for the nonparametric computation of $90 \%$ confidence limits for each reference limit (Clinical and Laboratory Standards Institute [17] 2008). While we originally recruited a minimum of 120 participants for each age range, we were able to use $<120$ participants for some analytes due to the exclusion of outliers. Second, our infant values for potassium were quite high, likely in part due to haemolysis and the inherent difficulty in obtaining blood draws from our youngest cohort. Third, we did not record anthropometric data on study participants, which might have enabled us to detect some cases of malnutrition. This may have been important as the nutritional status of a child can affect certain biochemistry parameters. However, children meeting criteria for severe malnutrition (such as marasmus or kwashiorkor) would not have been eligible for study participation, simply because of ill appearance. The study nurses were quite experienced in identifying such children, and it would be unlikely that mild or even moderate malnutrition, which could be overlooked with- out anthropometric data, would considerably alter plasma chemistries. Finally, the children in our cohort were not required to fast before laboratory testing, and therefore, all cholesterol and triglyceride levels are nonfasting. Whether children truly need to be in a fasting state prior to lipid screening is somewhat debatable. A review of over 12000 children with lipid levels (total cholesterol, triglycerides, LDL and HDL) collected via the National Health and Nutrition Examination Survey (NHANES), compared non-fasting children with fasting children. The results yielded only small differences in lipid levels that the authors conclude are not clinically meaningful [29]. Still, our values are higher than for US reference ranges, particularly for total triglycerides, and ideally, these should be repeated in a fasting state for those children with abnormal levels.

In conclusion, to our knowledge, we have established the first set of locally validated biochemistry reference intervals for children in Tanzania. These reference intervals demonstrate that healthy African children do not always have the same reference values for some parameters as their US or European counterparts of the same age. This information will provide physicians in Tanzania with the appropriate ranges they need to correctly interpret laboratory data and provide the highest quality of care to patients, and will assist researchers and scientists in the correct management of clinical trials participants to ensure proper management of study participants and the highest quality research data.

\section{Acknowledgements}

We thank the staff and patients of the Kilimanjaro Christian Medical Centre and Mawenzi Regional Hospital, and Sisters Bona Shirima, Janeth Kimaro, and Julitha Kimbi for assisting with participant recruitment and enrolment, and Philoteus Sakasaka for assisting with laboratory support. This research was supported by NIH award International Studies of AIDS-associated Co-infections. We received additional support from the Duke Clinical Trials Unit and Clinical Research Sites, the AIDS International Training and Research Programme, Fogarty International Center, and Duke University Center for AIDS Research. This research was supported in part by the International Maternal Pediatric Adolescent AIDS Clinical Trials Group (IMPAACT). Overall support for IMPAACT was provided by the National Institute of Allergy and Infectious Diseases, the Eunice Kennedy Shriver National Institute of Child Health and Human Development, and the National Institute of Mental Health. The content is solely the responsibility of the authors and does not necessarily represent the official views of the NIH. 
A. M. Buchanan et al. Biochemistry parameters for Tanzanian youth

\section{References}

1. Droke EA, Kennedy TS, Hubbs-Tait L. Potential for misclassification of micronutrient status in children participating in a Head Start program. J Am Diet Assoc 2006: 106: 376-382.

2. Ogunkeye OO, Roluga AI, Khan FA. Resetting the detection level of cord blood thyroid stimulating hormone (TSH) for the diagnosis of congenital hypothyroidism. J Trop Pediatr 2008: 54: 74-77.

3. Kibaya RS, Bautista CT, Sawe FK et al. Reference ranges for the clinical laboratory derived from a rural population in Kericho, Kenya. PLoS ONE 2008: 3: e3327.

4. Lugada ES, Mermin J, Kaharuza F et al. Population-based hematologic and immunologic reference values for a healthy Ugandan population. Clin Diagn Lab Immunol 2004: 11: 29-34.

5. Quinto L, Aponte JJ, Sacarlal J et al. Haematological and biochemical indices in young African children: in search of reference intervals. Trop Med Int Health 2006: 11: 17411748.

6. Buchanan AM, Muro FJ, Gratz J et al. Establishment of haematological and immunological reference values for healthy Tanzanian children in Kilimanjaro Region. Trop Med Int Health 2010: 15: 1011-1021.

7. United Nations Development Programme. Human Development Reports. New York, NY: UNDP, 2014. (Available from: http://hdr.undp.org/en/countries/profiles/TZA) [07 July 2015]

8. National Bureau of Statistics. Tanzanian Demographic and Health Survey. ICF Macro: Dar es Salaam, Tanzania, 2010.

9. Gething PW, Patil AP, Smith DL et al. A new world malaria map: Plasmodium falciparum endemicity in 2010. Malar J 2011: 10: 378.

10. Crump JA, Morrissey AB, Nicholson WL et al. Etiology of severe non-malaria febrile illness in Northern Tanzania: a prospective cohort study. PLoS Negl Trop Dis 2013: 7: e2324.

11. Abubakar A, Uriyo J, Msuya SE, Swai M, Stray-Pederson B. Prevalence and risk factors for poor nutritional status among children in the Kilimanjaro region of Tanzania. Int J Environ Res Public Health 2012: 9: 3506-18.

12. Mayhood MK, Afwamba IA, Odhiambo CO et al. Validation, performance under field conditions, and cost-effectiveness of Capillus HIV-1/HIV-2 and determine HIV-1/2 rapid human immunodeficiency virus antibody assays using sequential and parallel testing algorithms in Tanzania. J Clin Microbiol 2008: 46: 3946-3951.
13. Box G, Cox DR. An analysis of transformations. J Roy Stat Soc 1964: 26: 211-252.

14. Horn PS, Feng L, Li Y, Pesce AJ. Effect of outliers and nonhealthy individuals on reference interval estimation. Clin Chem 2001: 47: 2137-2145.

15. Tukey J. Exploratory Data Analysis. Addison-Wesley: Reading, MA, 1977.

16. Hahn GJ, Meeker WQ. Statistical Intervals: A Guide for Practitioners. John Wiley \& Sons: New York, NY, 1991.

17. Clinical and Laboratory Standards Institute (CLSI). Defining, Establishing, and Verifying Reference Intervals in the Clinical Laboratory. Approved Guideline. Laboratory Standards Institute: Wayne, PA, 2008.

18. Arcara KM. Blood chemistries and body fluids. In: Tschudy MM \& Arcara KM (eds). The Harriet Lane Handbook. Elsevier Mosby: Philadelphia, PA, 2012.

19. DAIDS. Division of AIDS Table for Grading the Severity of Adult and Pediatric Adverse Events. DAIDS: Bethesda, MD, USA, 2004.

20. Huh SY, Feldman HA, Cox JE, Gordon CM. Prevalence of transient hyperphosphatasemia among healthy infants and toddlers. Pediatrics 2009: 124: 703-709.

21. Bakerman S. ABC's of Interpretive Laboratory Data, 1994.

22. Domico MB, Huynh V, Anand SK, Mink R. Severe hyperphosphatemia and hypocalcemic tetany after oral laxative administration in a 3-month-old infant. Pediatrics 2006: 118: e1580-1583.

23. Kliegman R, Stanton BF, St Geme JW, Schor NF, Behrman RE. Hyperphosphatemia. In: Kliegman, Robert $\mathrm{M}$ and Stanton Bonita MD (ed.) Nelson Textbook of Pediatrics. Elsevier: Philadelphia, PA, 2011.

24. Gallucci F, Buono R, Ferrara L, Madrid E, Miraglia S, Uomo G. Chronic asymptomatic hyperamylasemia unrelated to pancreatic diseases. Adv Med Sci 2010: 55: 143-145.

25. Mortele KJ, Wiesner W, Zou KH, Ros PR, Silverman SG. Asymptomatic nonspecific serum hyperamylasemia and hyperlipasemia: spectrum of MRCP findings and clinical implications. Abdom Imaging 2004: 29: 109-114.

26. Gullo L, Migliori M. Benign pancreatic hyperenzymemia in children. Eur J Pediatr 2007: 166: 125-129.

27. Gullo L, Migliori M, Fusaroli P, Caletti G. Familial association of benign pancreatic hyperenzymaemia and pancreatic cancer. Gut 2007: 56: 1323-1324.

28. Koda YK, Vidolin E. Familial hyperamylasemia. Rev Hosp Clin Fac Med Sao Paulo 2002: 57: 77-82.

29. Steiner MJ, Skinner AC \& Perrin EM. "Fasting might not be necessary before lipid screening: a nationally representative cross-sectional study".Pediatrics 2011: 128: 463-470.

Corresponding Author Ann M. Buchanan, Division of Infectious Diseases, Department of Pediatrics, Duke University, Durham, NC, USA. E-mail: ann.buchanan@duke.edu 